\title{
Monitoring the nutritional value and chemical safety of the main feeds of the Republic of Tatarstan according to the results of studies carried out in 2019
}

\author{
(C) Alsu R. Makaeva, ${ }^{*+}$ Oksana V. Shlyamina, and Igor M. Fitsev \\ Federal Center for Toxicological, Radiation and Biological Safety (FSBSI «FCTRBS-RRVI»). \\ Nauchnyi Gorodok-2.Kazan. 420075.Republic of Tatarstan.Russia.E-mail: ic@vnivi.ru
}

\begin{abstract}
*Supervising author; ${ }^{+}$Corresponding author
Keywords: monitoring, assessment of feed nutritional value, farm animals feeding, physical and chemical methods of analysis, protein, dry matter, pesticides.
\end{abstract}

\begin{abstract}
Production of high-quality food of animal origin directly depends on the health of farm animals. Feeding of farm animals balanced in terms of nutrients is the most important condition for improving the quality of livestock production and its productivity. The productivity of animals depends on providing their organisms with all the necessary nutrients and biologically active substances. Along with the nutritional value, chemical safety of feed is also important for animals and humans. Pesticides have a special place among chemical toxicants. The article presents the monitoring of the nutritional value and chemical safety of the main feeds of agricultural producers of the Republic of Tatarstan, based on the results of their physical and chemical studies carried out in 2019 by of "FCTRBS". The feed was tested for content of crude protein, moisture, crude fat, crude fiber, ash, and pesticides in accordance with the test methods included in the scope of accreditation of Test Center. $94.4 \%$ of feed for farm animals in the Republic of Tatarstan meet the requirements for nutritional value and chemical safety, which are imposed on them by the current regulatory and technical documentation. Only 5.6\% of the studied feeds did not meet the physical and chemical parameters (the content of crude protein, crude fat, moisture, ash). A comprehensive assessment of the results of physical and chemical studies shows that agricultural feed producers in the Republic of Tatarstan comply with the basic requirements of the normative and technical documentation for the nutritional value and chemical safety of feed for farm animals. The latter determines not only the quality of animal husbandry, but also its efficiency and productivity.
\end{abstract}

\section{References}

[1] A.R. Makaeva, V.I. Stepanov. Evaluation of crude protein content in feed of the Republic of Tatarstan in 2017. Current problems of veterinary medicine: materials of international scientific and practical conference dedicated to the 90th anniversary of the birth of Professor V. A. Kirshin. FCTRBS. Kazan. 2018. P.151-153. (russian)

[2] N. Kravchenko, M. Monin. Effective enzymes for the poultry industry. Poultry. 2006. No.4. P.26-27. (russian)

[3] A.V. Malanyev, D.V. Aleev, G.G. Galyautdinova, V.I. Egorov, E.N. Ivanov. Toxicologycal evaluation of feed from the Republic of Mordovia for the presence of pesticides and nitrogen-containing compounds. The veterinarian. 2019. Vol.2. P.43-49. (russian)

[4] GOST R (Russian National Standard) 31481-2012 Mixed fodders, raw stuff for mixed fodders. Method for determining the residual quantities of chlorine-organic pesticides. Standartinform, Moscow. 2012. (russian)

[5] Determination of pesticide residues in food, agricultural raw materials and environmental objects. Collection of guidelines. MUK 4.1.2162-4.1.2176-07. 4.1. Control method. Chemical factor. [Electronic resource]. URL: http://docs.cntd.ru/document/1200079314 (date of request 06.05.2020). (russian)

[6] GOST R (Russian National Standard) 8.736-2011. State system for ensuring the uniformity of measurements. Multiple direct measurements. Methods of measurement results processing. Main principles. Standartinform, Moscow. 2013. (russian)

[7] GOST R (Russian National Standard) 34100.1-2017/ ISO/IEC Guide 98-1:2009. Uncertainty of measurement. Part 1. Introduction to guides on the expression of uncertainty in measurement. Standartinform, Moscow. 2018. (russian) 
[8] Z.B. Komarova, S.I. Nikolaev, S.M. Ivanov. Biological features and technology of poultry feeding: textbook. Volgograd: FSBEI HE Volgograd SAU. 2012. 96p. (russian)

[9] GOST ISO 6497-2014 Feeding stuffs. Sampling. Standartinform, Moscow. 2014. (russian)

[10] GOST 13496.4-93 Fodder, mixed fodder and animal feed raw stuff. Methods of nitrogen and crude protein determination. Standartinform, Moscow. 1993. (russian)

[11] GOST 13496.15-2016 Feeds, mixed feeds, feed raw material. Methods for determining the raw fat content. Standartinform, Moscow. 2016. (russian)

[12] GOST R (Russian National Standard) 54078-2010 Fodder wheat. Specifications. Standartinform, Moscow. 2011. (russian)

[13] GOST R (Russian National Standard) 53900-2010 Feed barley. Specifications. Standartinform, Moscow. 2011. (russian)

[14] ГОСТ P 54079-2010 Рожь кормовая. Технические условия. М.: Стандартинформ. 2011. GOST R (Russian National Standard) 54079-2010 Feed rye. Specifications. Standartinform, Moscow. 2011. (russian)

[15] GOST R (Russian National Standard) 53901-2010 Feed oat. Specifications. Standartinform, Moscow. 2011. (russian)

[16] ГОСТ Р 53903-2010 Кукуруза кормовая. Технические условия. М.: Стандартинформ. 2011. GOST R (Russian National Standard) 53903-2010 Feed Corn. Specifications. Standartinform, Moscow. 2011. (russian)

[17] GOST R (Russian National Standard) 54630-2011 Fodder peas. Specifications. Standartinform, Moscow. 2012. (russian)

[18] GOST R (Russian National Standard) 51550-2000 Mixed feeds-concentrates for pigs. General specifications. Mixed feeds. Part 1. Mixed feeds-concentrates. Specifications. Moscow. PPK Publishing house of standards. 2002. (russian)

[19] GOST 34109-2017 Complete mixed feeds for pigs. General specifications. Standartinform, Moscow. 2017. (russian)

[20] GOST 18221-99 Mixed full-ration feeds for poultry. Specifications. Mixed feeds. Part 1. Mixed feedsconcentrates. Specifications. Moscow. PPK Publishing house of standards. 2002. (russian)

[21] GOST 9268-2015 Mixed feeds-concentrates for fodder cattle. Specifications Standartinform, Moscow. 2016. (russian)

[22] GOST R (Russian National Standard) 57221-2016 Nutrient yeast. Test methods. Standartinform, Moscow. 2016. (russian)

[23] ГОСТ 31809-2012 Барда кормовая. Технические условия. М.: Стандартинформ. 2013. GOST 31809-2012. Nutrient stillage. Specifications. Standartinform, Moscow. 2013. (russian)

[24] Hygienic standards for the content of pesticides in environmental objects (list): HS 1.2.3539-18. Bulletin of normative and methodological documents of the state sanitary and epidemiological supervision service. 2019. Vol.3(77). P.7-103. (russian) 